\title{
Modeling of Rainfall and Ground Water Fluctuation of Gonda District Uttar Pradesh, India
}

\author{
Dinesh Kumar Vishwakarma ${ }^{1 *}$, Rohitashw Kumar ${ }^{2}$, Kusum Pandey $^{3}$, \\ Vikash Singh $^{4}$ and Kuldeep Singh Kushwaha ${ }^{5}$
}

${ }^{1,2}$ College of Agricultural Engineering and Technology, Sher-e-Kashmir University of Agricultural Sciences and Technology of Kashmir, Shalimar Campus SrinagarJammu and Kashmir, India

${ }^{3}$ Department of Soil and Water Conservation Engineering, Punjab Agricultural University, Ludhiana, Punjab 141004, India

${ }^{4}$ Department of Farm Engineering, Institute of Agricultural Sciences, Banaras Hindu

University, Varanasi 221005

${ }^{5}$ Centre of Water Engineering and Management, Central University of

Jharkhand - 835205, India

*Corresponding author

\begin{tabular}{|c|c|}
\hline & A B S T R A C T \\
\hline & $\begin{array}{l}\text { Various quantitative analyses are required for complex and dynamic nature of water } \\
\text { resources systems to manage it properly. Groundwater table fluctuations over time in }\end{array}$ \\
\hline Keywords & $\begin{array}{l}\text { shallow aquifer systems need to be evaluated for formulating or designing an } \\
\text { appropriate groundwater development scheme. This paper demonstrates a methodology }\end{array}$ \\
\hline $\begin{array}{l}\text { Precipitation, } \\
\text { Ground water } \\
\text { recharge, Ground } \\
\text { water table } \\
\text { fluctuation, Karl } \\
\text { Pearson's } \\
\text { correlation }\end{array}$ & $\begin{array}{l}\text { for modeling rainfall- runoff and groundwater table fluctuations observed in a shallow } \\
\text { unconfined aquifer Gonda District Utter Pradesh. The rainfall recharge contributed to its } \\
\text { annual increment in the ground in water reserve which in turn is reflected in the rise of } \\
\text { water table during the post monsoon period. The linear regression model between water } \\
\text { table and annual rainfall was derived by Karl parson's method. The coefficient of } \\
\text { correlation between rainfall and ground water table was found }-0.70 \text {. The value of } \\
\text { statistical errors of } \mathrm{R}^{2} \text {, ME, RMSE and EC were found to be } 0.438,0.213365 \text { and - }\end{array}$ \\
\hline Article Info & $\begin{array}{l}0.92173 \text { respectively. The fitted models, values of fluctuation determination } \mathrm{R}^{2} \text { was found } \\
\text { to be significant close to observed value. It has been found that fluctuation was more as }\end{array}$ \\
\hline $\begin{array}{l}\text { Accepted: } \\
20 \text { April } 2018 \\
\text { Available Online: } \\
10 \text { May } 2018\end{array}$ & $\begin{array}{l}\text { compare the availability. A good correlation was found between seasonal rainfall and } \\
\text { change in ground water level. The increment in ground water reserve, correlation between } \\
\text { climatic parameter and ground water level showed positive and negative relationship. } \\
\text { Highest correlation was found in rainfall and ground water level. The developed equation }\end{array}$ \\
\hline & $\begin{array}{l}\text { may be adopted for reasonable estimate of ground water table depth at piezo metric } \\
\text { stations based on depth for the effective planning and management of ground water } \\
\text { resources of the basin. }\end{array}$ \\
\hline
\end{tabular}




\section{Introduction}

Indian agriculture received the highest priority in irrigation development in successive five year plan under ground water. Groundwater is one of the major sources of supply for domestic, industrial, and agricultural purposes. Various quantitative analyses are required for complex and dynamic nature of water resources systems to manage it properly (Adhikary et al., 2012). More than half of the total irrigation done through ground water, the share of ground water in the total irrigated area under increasing form 30 percent in 1960-61 to 58.77 percent in 1999-2000 (Chandra, 1979; CGWB, 1995; Hiscock et al., 2002). The area underground water is increasing progressively as this is the most reliable and cost effective source of irrigation. The rainfall recharge contributed to its annual increment in the ground water reserve which in turn is reflected in the rise of water table during the post monsoon period (Kumar and Seethapathi, 2002). Estimation of water table is essential for planning and developing the resources. With increasing the demand of water for both agriculture and industrial use, it is urgent need to develop ground water resources. Groundwater table fluctuations over time in shallow aquifer systems need to be evaluated for formulating or designing an appropriate groundwater development scheme. Models can be simple images of things or can be complex, carrying all the characteristics of the object or process. They represent (Chen et al., 2002; Daliakopoulos et al., 2005; Adhikary et al., 2012).

The fluctuation of water table is mainly depending upon the precipitation received in the area and ground water utilization by various purposes (Chand et al., 2005). Simulation of ground water behavior is required to predict water table fluctuation in response to varying ground water pumping and recharge conditions (Bhattacharya, 2007;
Romani, 2009). Ground water model are widely used for simulation of ground water behavior. The present study of modeling of rainfall and ground water fluctuation of Gonda Distract was conducted to evaluate the relationship between rainfall and ground water fluctuation.

\section{Materials and Methods}

The study was conducted to develop the model for the predicted and relationship between rainfall and ground water fluctuation of Gonda district (U. P.) through regression analysis and correlation between rainfall and water table depth.

\section{Study area}

The study conducted at Gonda districts of Uttar Pradesh, which is located between $26^{\circ} 47^{\prime}$ and $27^{\circ} 20^{\prime}$ north latitude and 81 ${ }^{\circ} 30^{\prime}$ and $82^{\circ} 46^{\prime}$ east longitude. The holy rivers Saryu and Ghaghara pass through the district. The fluvial soils deposits of these two rivers, making it one of the most productive soils in the Tarai region. The average summer temperature is nearly $34^{\circ} \mathrm{C}$ with average rainfall is $1152 \mathrm{~mm}$ (Fig. 1).

The ground water data from 2000-2010 was collected from ground water department of Gonda district which is summarized in Table 1. The grounder water data, regression corelation was analyzed. The rainfall $(\mathrm{mm})$ is denoted by " $\mathrm{X}$ " whereas depth of water table (m) is denoted by "Y" using Karl Pearson's Methods.

The quantitatively performance of model as regard to computation of water table was compared with one another by determining several statistical measures such as mean error (ME), root mean square error(RMSE) and efficiency coefficient (EC) were used. These criteria can be calculated from Equation's. 1, 
2, and 3, respectively (Willmott et al., 2012):

$\mathrm{ME}=\frac{1}{N}\left|\sum_{i=1}^{N}\left(P_{i}-O_{i}\right)\right|$

RMSE $=\frac{1}{N}\left|\sum_{i=1}^{N}\left(P_{i}-O_{i}\right)^{2}\right|^{0.5}$

$E C=1-\frac{\sum_{i=1}^{N}\left(P_{i}-O_{i}\right)^{2}}{\sum_{i=1}^{N}\left(O_{i}-\bar{O}\right)^{2}}$

Where $N$ is the total number of data, $P$ and $O$ are referred to the predicted and observed data, respectively, and $\bar{O}_{\text {is }}$ the mean value of observed data.

\section{Results and Discussion}

The hydrological measurement and collection of hydrological data used in the study was collected. The Karl Pearson's method was used for predicting ground water table. The statistical errors (Coefficient of efficiency and root mean square error) were determined to judge the adequacy of the model, qualitative and quantitative. The comparison of observed and predicted water table are resented and discussed in this section. The rainfall data and observed water table depth during 2000 to
2010 is shown in table 1.It is evident from table 1 that maximum water table depth fluctuate was found $5.77 \mathrm{~m}$ during 2009 .

On the basic of 11 years data regression equation water table and annual rainfall of Gonda district was derived by Karl Pearson's method. The coefficient of correlation between water table and rainfall was -0.70.It is evident from Table 1 that the ground water table in Gonda varies 4.20 to 5.77. It's evident from the data that the water table changed according to rainfall. The rainfall in Gonda district varies from 797.13 to $1375.73 \mathrm{~mm}$. The annual predicted water table in $(\mathrm{m})$ of study area is shown in table 2.The developed equation model (regression line) which was used is given below

$$
Y^{\prime}=-0.0021 X+6.8424
$$

Where,

$\mathrm{Y}^{\prime}=$ predicted water table

$\mathrm{X}=$ observed rainfall

Table.1 Rainfall and depth of water table during 2000-2010

\begin{tabular}{|c|c|c|}
\hline Year & $\begin{array}{c}\text { Rainfall }(\mathbf{m m}) \\
(\mathbf{X})\end{array}$ & Depth of water table (m) $(\mathbf{Y})$ \\
\hline $\mathbf{2 0 0 0}$ & 979.81 & 4.45 \\
\hline $\mathbf{2 0 0 1}$ & 1190.45 & 4.23 \\
\hline $\mathbf{2 0 0 2}$ & 811.75 & 4.67 \\
\hline $\mathbf{2 0 0 3}$ & 1230.32 & 4.28 \\
\hline $\mathbf{2 0 0 4}$ & 931.79 & 5.54 \\
\hline $\mathbf{2 0 0 5}$ & 1140.67 & 4.20 \\
\hline $\mathbf{2 0 0 6}$ & 997.47 & 4.46 \\
\hline $\mathbf{2 0 0 7}$ & 797.13 & 5.77 \\
\hline $\mathbf{2 0 0 8}$ & 973.45 & 4.76 \\
\hline $\mathbf{2 0 0 9}$ & 1375.73 & 4.27 \\
\hline $\mathbf{2 0 1 0}$ & 1035.56 & 4.38 \\
\hline
\end{tabular}


Table.2 Annual observed and predicted water table in (m) of Gonda District (U.P.)

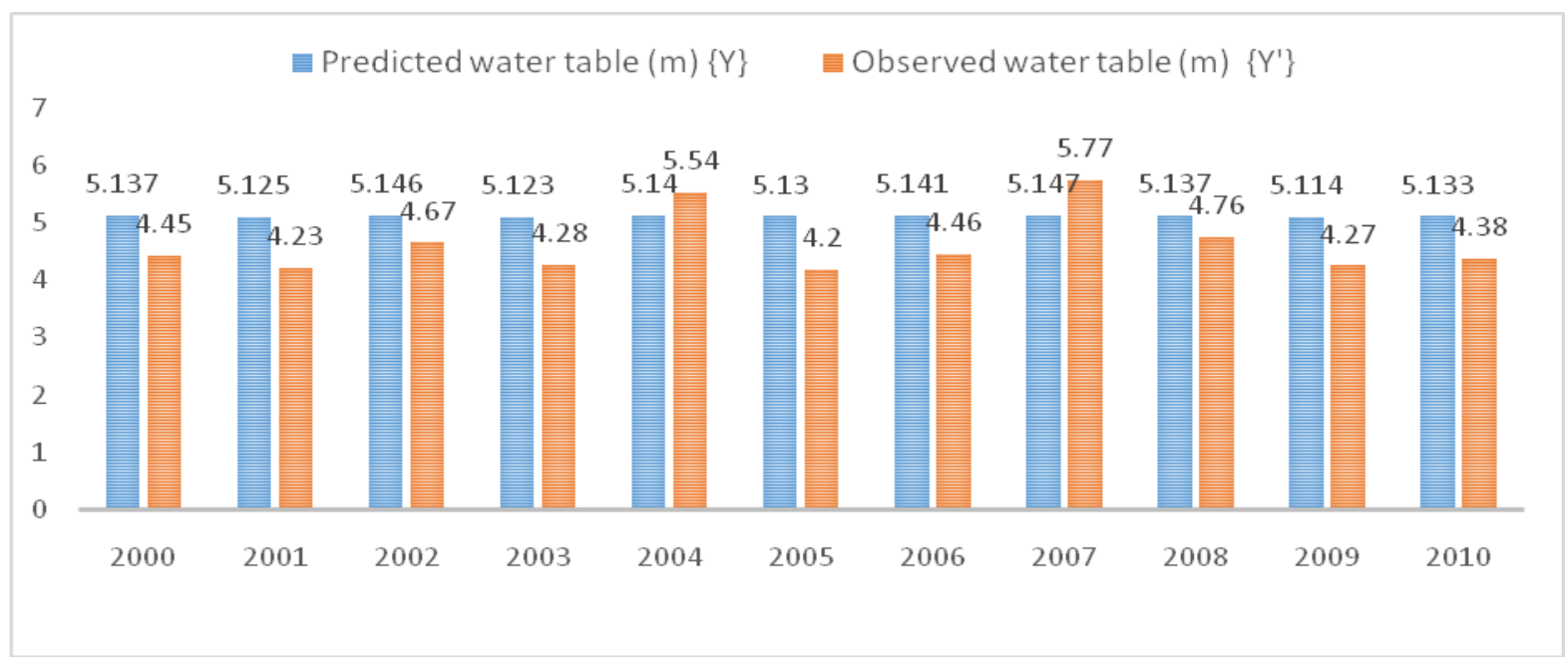

Fig.1 Location map of the area

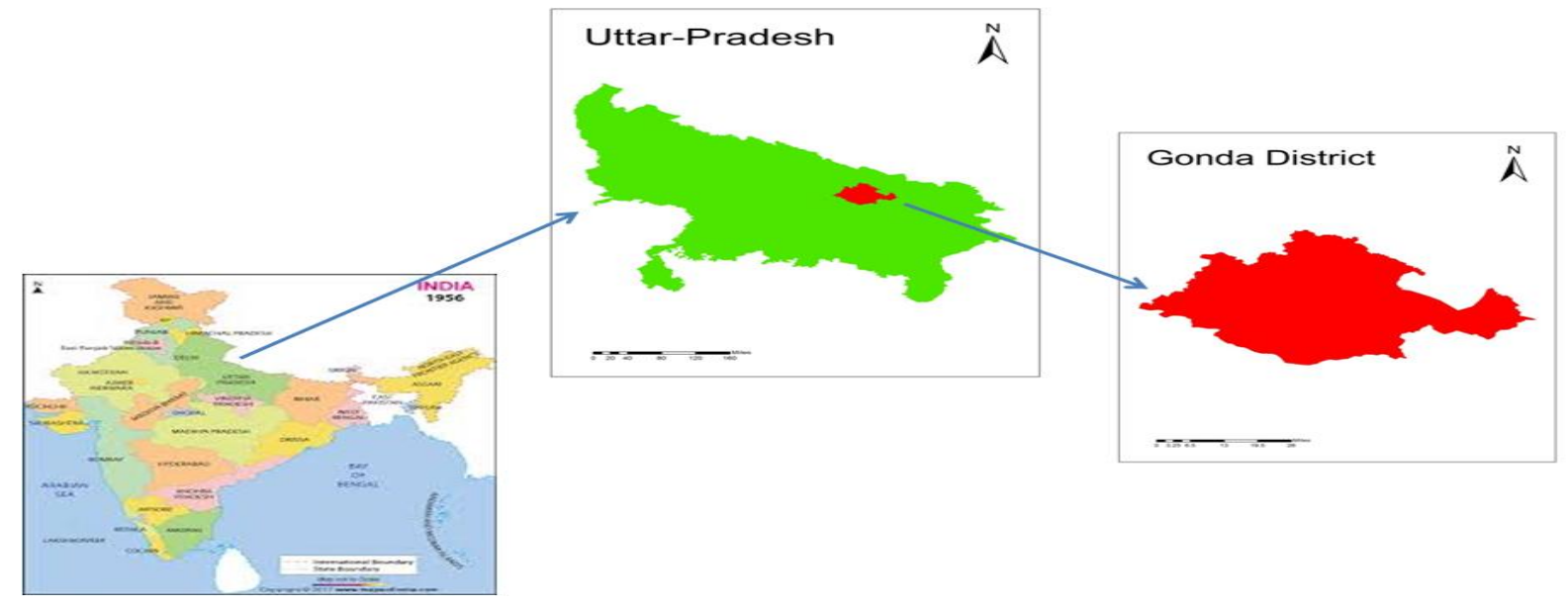

Fig.2 Correlation and regression line between rainfall and ground water table

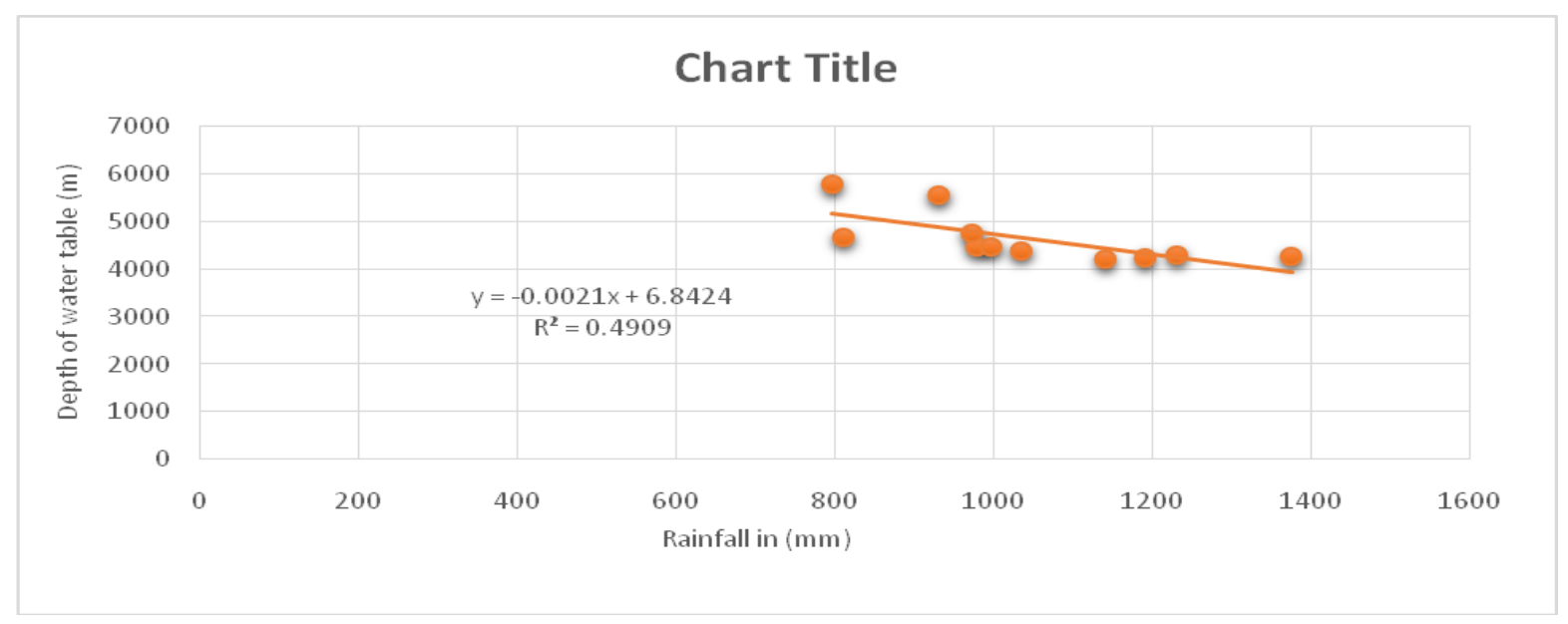


The error statistics results have been evaluated through $\mathrm{R}^{2}$, ME, RMSE and EC. The value of $\mathrm{R}^{2}$, RMSE and EC were found between predicted and observed value is $0.438, \quad 0.496636, \quad 0.213365$ and

0.92173 respectively. The higher value of $\mathrm{R}^{2}$, effective planning and management can do for ground water resource in the area. The efficiency coefficient indicates a very satisfactory model performance while a value in the range $80 \%-90 \%$. The annual Observed and Predicted water table is summarized in Table 2. It is evident from Table 2 that error statistics are in good agreement with predicted and observed value of water table. Mean error (ME), root mean square error(RMSE) and efficiency coefficient (EC) were found in between predicted and observed ground water table is 0.496636 , 0.213365 and -0.92173 respectively (Fig. 2).

In conclusion, the linear regression model between water table and annual rainfall of Gonda district was derived by Karl parson's method. The correlation between predicted and observed value of ground water table is 0.438 . The value of $R^{2}$, ME, RMSE and EC between predicted and observed ground water table using liner regression model were found to be $0.438,0.496636,0.213365$ and -0.92173 respectively. The fitted models, values of fluctuation $R^{2}$ was found to be significant indicating good fit of model. The modeled value of $\mathrm{R}^{2}$ was $67 \%$. It has been found that fluctuation in water table was more as compare to availability. The developed equation may be adopted for reasonable estimate of ground water table depth at piezo metric stations.

\section{Acknowledgements}

The authors are grateful to Er. MahendraRai and Dr. R. K. Mehta, Associate Professors, Department of Soil and Water Conservation Engineering, NDUAT Faizabad (U.P) for providing all facilities to conduct this study.

\section{References}

Adhikary, S.K., Rahman, M.M. and Gupta A.D. 2012. A stochastic modelling technique for predicting groundwater table fluctuations with time series analysis. Int. Journal of Applied Sciences and Engineering Research. 1(2), 238-249.

Bhattacharjee, A.P., Jindal, S.R. and Srivastava, B.P. 1953. Penetration of Rainwater to Groundwater table in Duab West of the Ganga River, U.P.I.R.I. Tech. Memo. No. 24.

CGWB.1995.Groundwater resources of India. Faridabad, India, central ground water board, ministry of water resources, Government of India.

Chandra, S. 1979. Estimation and measurement of recharge to ground water from rainfall, irrigation an influent seepage, proceeding, international seminar on development and measurement of ground water resources, 5-20 November 1979, School of hydrology, university of Roorkee, p.p. iii-9, to iii-17.

Chen, Z., Grasby, S.E. and K. G. Osadetz, K.G. 2002. Predicting average annual groundwater levels from climatic variables: an empirical model. Journal of Hydrology, 260(1-4) $102-117$.

Daliakopoulos, I. N., Coulibaly, P. and Tsanis, I. K. 2005. Groundwater level forecasting using artificial neural networks," Journal of Hydrology, 309(1-4): 229 - 240.

Hiscock, K. M., Rivett, M. O., and Davison, R. M. 2002. Sustainable ground water development. Geological Society, London, Special Publications, 193, 114. doi:10.1144/GSL.SP.2002.193.01. 01

Kumar, C. P. and Seethapathi, P. V. 2002. Assessment of Natural Groundwater Recharge in Upper Ganga Canal 
Command Area. Journal of Applied Hydrology, Association

Hydrologists of India, 15(4), 13-20.
Willmott, C. J., Robeson, S. M., and Matsuura, K. 2012. A refined index of model performance. Int. J. Climatol. 32, 2088-2094.

\section{How to cite this article:}

Dinesh Kumar Vishwakarma, Rohitashw Kumar, Kusum Pandey, Vikash Singh and Kuldeep Singh Kushwaha. 2018. Modeling of Rainfall and Ground Water Fluctuation of Gonda District Uttar Pradesh, India. Int.J.Curr.Microbiol.App.Sci. 7(05): 2613-2618. doi: https://doi.org/10.20546/ijcmas.2018.705.302 